\title{
ХУДОЖНЬО-СТИЛЬОВІ ОСОБЛИВОСТІ МЕМУАРНОЇ ПРОЗИ ЯК ФЕНОМЕНА КУЛЬТУРИ Й ХУДОЖНЬОЇ СЛОВЕСНОСТІ
}

\author{
Кандюк-Лебідь С. В.
}

\section{Вступ}

Мемуарна література $\epsilon$ одним із важливих чинників духовного самовираження нації. Завдяки цьому унікальному жанрові маємо змогу глибше простежити поступ громадської думки, розвиток суспільного життя, пізнати внутрішній світ людини, якій належать спогади. Мемуари дають те, чого здебільшого бракує белетристиці й науковим дослідженням, - вони демонструють суспільно-політичні, економічні, духовно-культурні проблеми життя нації через суб'єктивність конкретного сприйняття, яке є опозиційним до офіційної ідеології або ж проливає світло на певні факти, вчинки.

В Україні мемуарна література розвивалася порівняно скромно. Громадсько-політичне і культурне життя, придушуване царатом, не сприяло їі розвиткові. Проте в таких виданнях другої половини ХІХ ст., як «Основа», «Зоря», «Правда», «Киевская старина», друкували чимало матеріалів мемуарного характеру.

Малозадовільний стан 3 вивченням значного натепер материка української мемуаристики взагалі та спогадового пласту літератури кінця XVIII - початку XIX ст., неабиякі iї можливості в духовному оздоровленні сучасного суспільства диктують настійну потребу в докладному науково-критичному дослідженні, вивченні іiі природи та шляхів розвитку.

У сучасній історичній науці мемуари вивчаються 3 методологічної перспективи в межах проблематики «образ свого» - «образ іншого», а також 3 обсягу проблем ментальностей, етнічних та соціальних стереотипів, міфів, семантичного, етнопсихологічного та етносоціологічного аналізу, формацій історії пам'яті тощо. Зокрема, застосовуються спеціальні методики для вилучення суб'єктивних суджень чи ціннісних настанов, які зумовлені становими, расовими, релігійними, етнічними, авто- та гетеростереотипами, впроваджуються новітні верифікаційні процедури тощо. Заразом аналізується жанрова та стильова природа мемуарів, зокрема, спомини вивчаються як своєрідний метатекст культури, метажанр его-тексту конкретної особистості тощо. Мемуарний образ (героя, автора) є сполученням 
об'єктивної реальності й індивідуального ставлення до неї, що породжує можливість інтерпретувати оригінал у межах історичної вірогідності. У цьому разі документальну основу образу доповнюють художні прийоми його відтворення, а зміст життя перетворюють на художній зміст. 3 одного боку, у мемуарних образах закладено інформаційний аспект, з іншого - його творчу трансформацію.

Образи спогадового тексту несуть у собі відбиток двійчастості природи цього жанру. У рамках твору сукупність конкретних i узагальнених образів становить єдину систему, всі елементи якої взаємозалежні.

\section{1. Система персонажів та засоби творення образів спогадового тексту}

Мемуарний текст, як і будь-який, має власну систему образів, яка, попри неповторність самовираження кожного автора, має спільні риси 3 іншими творами. Так, незважаючи на унікальність кожного мемуарного тексту, всі вони вибудовуються за аналогічною схемою, яка стала традиційною для жанру мемуарів: починається мемуарний твір з походження героя, де подаються подробиці про його дитинство, батьків, рідних. Автор описує визначні події або пригоди, які мали місце в його житті. Наступним кроком автор завжди описує юність, іiі яскраві події, складнощі, становлення особистості, особисті переживання тощо. Залежно від віку письменника та від того, що саме він хотів зобразити в своєму мемуарному творі, можуть описуватись події з дорослого життя, старості.

За аналогією незалежно від змісту та індивідуального стилю автора мемуарні твори мають спільну систему образів, яку, за типологією M. Епштейна ${ }^{1}$, можна розподілити на три групи: 1) залежно від предмета образності; 2) залежно від змісту образу; 3) залежно від співвідношення предметного та смислового аспектів.

Відштовхуючись від запропонованої класифікації М. Епштейна, проаналізуємо жанрово-стильові особливості творів мемуарного пласту української літератури початку XIX ст., доповнивши іiі власними результатами аналізу.

1.1. Образи, які згруповано за предметом образності, утворюються за допомогою таких лексичних засобів, як: використання великої кількості епітетів; використання великої кількості порівнянь; статистична інформація; застосування правдивих дат, кількісних показників; застосування одиниць мір, грошових одиниць; застосування реалій, характерних для першої частини XIX ст.

1 Эпштейн М. Проективный словарь философии. Новые понятия и термины. URL: http://topos.ru/article/1676. 
Образи, які згруповано за предметом образності, включають у себе:

1. Деталізацію - впровадження в текст мемуарів найдрібніших одиниць предметного зображення. Мемуарна деталізація базується на докладному зображенні деталей інтер'єрів, описі подій з життя автора та оточуючих його людей, докладному описанні переміщень, детальному зображенні історичних подій, яким присвячено мемуарні спогади.

- Деталізачія опису інтер'єрів: «Для жительства нашего назначена была одна деревянная горница с двумя малыми окошками; а из сеней оной, весьма узки, дверь была в церковь, которая также была не пространна, и низка, под одною с келиею нашею кровлею» ${ }^{2}$ «Живо помню я этот скромный приют моего детства - хорошенький малороссийский домик с двумя чистыми комнатами, кухней и кладовой. Он был крыт очеретом (камышом) под гребенку, что служило знаком уже некоторой роскоши, ибо у прочих хуторян жилища скромно прятались под солому. На дворе стояли: большой сарай, конюшня, загородь с навесом для коров и овец и курятник. Но моё внимание особенно привлекали ворота. Над ними, по малороссийскому обычаю, была устроена голубятня, где жило, вило гнездо и выводило потомство многое множество голубей» ${ }^{3}$; «В огромных залах, устланных камышевыми коврами, находилось множество разного рода прислужников без башмаков, поставленных чинно в ряд у входа. Комната, в которой нас принял паша, была хорошо убрана, но ничто не давало понятия о каком-то волшебном богатстве и роскоши, которыми славится восток» ${ }^{4}$.

- Деталізація подій, переміщень героїв: «Переезд отсюда на житье в местечко Баклань, куда вотчим мой определен был сотником, гораздо явственнее помню»; «1806 года Августа 11-го я был определен юнкером 2 класса в С.-Петербургскую крепость, где и не служил более $11 / 2$ месяца» ${ }^{6}$; «А дабы более, еще учинить сего Антоновича привязанным к пользам Малороссийской республики, то была выдана за него в замужество невестка славнаго Малороссийскаго гетмана, Зиновия или Богдана Хмельницкаго, урожденная княжна Волохская

2 Фальківський Іриней. Біографические известия. IP НБУ ім. Вернадського. Ф. 175. № 2214. 100 c. С. 6.

${ }^{3}$ Никитенко А.В. Записки и дневник: в 3 т. Москва : Захаров, 2005. Т. 1. 640 с. C. 12 .

${ }^{4}$ Розальон-Сошальский А.Г. Записки русского офицера, бывшего в плену у турок в 1828 и 1829 годах. Харьков; Киев : Харьковский частный музей городской усадьбы; ИД «Стилос», 2006. 128 с. С. 30.

${ }^{5}$ Мое время. Записки Г.С. Винского; предисловие А.И. Тергенева. Русские люди XVIII века / отв. ред. О.А. Платонов. Москва : Институт русской цивилизации, 2015. C. 510.

${ }^{6}$ Записки инженерного офицера Мартоса. 1806-1812. Русский архив. 1893. Кн. 2. C. 305 . 
Ирина, дочь самовладетельнаго князя Василия Лупула, оставшаяся вдовою после убитаго на вылазке из столичнаго Валахскаго города Тимофея Хмельницкаго, сына гетманскаго, с знатным приданым, состоящим из города и со всеми усадьбами, землями и угодьями, принадлежавшими к оному, Зинькова, так названнаго по имени славнаго Зиновия Хмельницкаго, отданнаго за нею от гетмана Юрия Хмельницкаго по завещанию о том от его умершаго тогда родителя...»" .

- Деталізачія пейзажів, опису навколиншього світу: «Того ради пошел я далее, как внезапно со всех сторон открылось множество болот и заливов, которыя путь пересекли» ${ }^{8}$; «Отдаляясь, однако, напоминовениями, сколько можно, к тем временам, вижу, как будто в тумане, наш дом в деревне Котляковке; памятны сливныя деревья по дорогам в огороде; помню еще дальний огород, куда, шедши единожды с матерью, захвачены мы были грозою...»; «1-го Июня я получил позволение любопытствовать покоренную нами крепость. Внутри города нет ничего примечательного; но как это был почти первый Турецкий город, который я видел, то меня весьма занимали узкие и темные улицы, кофейные дома, где Турки с важностью сидя курили трубки, были к нам учтивы, подчивали кофеем и фруктами. <...> В городе все дома внутри дворов, и таким образом, проходя через лавки, где встречали часто зверообразные их физиономии, а другие добрые лица, дошли мы до цитадели. Все окрестное жилье к замку выжжено от канонады, и земля во дворах и на улицах изрыта бомбами; всюду валялись куски убивственного чугуна, - картина неприятная и печальная!» ${ }^{10}$.

- Деталізаиія архітектурних пам'яток: наряду 3 детальним описом навколишнього світу, зокрема, природи, автори мемуарів нерідко вдаються до опису архітектури, позаяк всі вони багато подорожують, отже, опис архітектури дає змогу передати читачеві побачене, відтворити світ автора в свідомості читача: «На 18-м году приехавши в Санкт-Петербург, виденные тогда предметы, как: недостроенныя две стороны Зимняго дворца, неочищенная пред ним площадь, зимовавший против Кунсткамеры, спущенный на Неву военный корабль, каменный сарай, где отливался Петра Великаго памятник, кристальный, у Семеновскаго моста, завод, даже первые гренадеры Измайловскаго полка, в их древних шапках и унтер-

7 Записки Михаила Ивановича Антоновскаго (Начаты въ 1806 году). Руский архив. Киев, 1885. Кн. 1. С. 146.

${ }^{8}$ Фальківський Іриней. ... С. 16.

${ }^{9}$ Мое время. Записки Г.С. Винского... С. 509-510.

10 Записки инженерного офицера Мартоса... С. 314. 
офицерския перевязи, так свежи в моей голове, будто я на них теперь гляжу» ${ }^{11}$; «Событія наступившаго 1667 года несчастливо сложились для Москвы и неминуемо должны были подготовить то, что вскоре произошло в Гетманщине. Утрата Москвой первенствующего значенія и ея вынужденное примиреніе с Польшей, ценою уступки исконным врагам украинскаго народа заветной его святыни - древняго Кіева, уступки, уничтожавшей политическое единство Украйны, произвед в последней удручающее впечатленіе» ${ }^{12}$.

2. Предметні образи - за допомогою предметних образів, автор мемуарного твору організовує художній простір та конкретизує існування персонажів як смислове, так і матеріальне. Подібні образи включають у собі образи-предмети, які характеризують особливості буття та життєдіяльності персонажів твору: «Купил я также для Прецептора часы песочныя, чтоб знать, когда ему отходить от нас: за 10 крейцеров, да бумаги за 4 дудки. Бриля да платка еще не купил, на ярмарку купит хозяйка» ${ }^{13}$; «Как теперь вижу приготовления к сему путешествию; вывезенные из шопы: берлин, коляски, таратайки, несколько возов и полуботов» ${ }^{14}$; «Везде были видны следы их нападений: сожженная деревня, в которой русские остались победителями, дорога, усеянная бумажками от патронов, разбитые ящики, повозки и пр.» ${ }^{15}$.

3. Образи-думки та образи-пережсивання. Особливою підгрупою групи предметних образів є образи-думки та образи-переживання. Ця підгрупа покликана продемонструвати внутрішній світ персонажів та власне автора. Підгрупа образи-думки та образи-переживання $\epsilon$ надзвичайно важливою з огляду на те, що саме з їх допомогою автор відкриває читачеві чуттєвий світ, надаючи документальному твору яскравості, емотивності, образності. Опис думок та переживань надає «життєвості» лаконічним та «сухим» фактам історичних та життєвих подій:

- Образи-відчуття: «Я немало огорчился, судом было его хотел искать: того ради объявил обиду свою Начальнику своему Декану, именем его к судье городскому безпутнаго ученика позвать» ${ }^{16}$; «Почтенный Каетан Николаевич меня любил как сына и заставил меня казаться и прослыть любезным, как говорят люди нынешнего света» ${ }^{17}$.

C. 199 .

${ }_{11}^{11}$ Мое время. Записки Г.С. Винского... С. 511.

12 Горленки (Очерки прилуцкой старины). Киевская старина. 1887. № 10.

13 Фальківський Іриней. ... С. 13.

${ }_{15}^{14}$ Мое время. Записки Г.С. Винского... С. 510.

${ }^{15}$ Розальон-Сошальский А.Г. Записки русского офицера... С. 10.

${ }^{16}$ Фальківський Іриней. ... С. 19.

17 Записки инженерного офицера Мартоса... С. 309. 
- Образи-думки: «Точно так, толико не ради того, что слово о ней приводит меня в гнев. Когда я слишком сердился, ежели вы говорили: я люблю вас? (хотя и гораздо учтивее сего было б, сказать: я люблю такого, как вы; а учтивее и благоразумнее всего было б, не говорить в глаза никогда ни того ни другого). Мысль ваша «возражения вам делала» «за что?» за любовь оную, происходящую, (по вашему мнению) от примечания моих совершенств? (но никто же благ и совершен (найпаче из юношей) только один Бог). <...> Итак не могла вам мысль ваша возражений делать, разве за любовь порочную: и делаем их за оную возражений, решить не можно. Однак вы решили...» ${ }^{18}$; «Дитя к десяти годам своего существования являет уже начатки страстей, имеющих некогда образовать его свойство. Сие время есть важнейшее в жизни, потому что тут должно чрез воспитание, добрыя склонности в юноше посеять, возрастить, усилить, как дурныя возникающия выполоть, искоренить, по меньшей мере ослабить» ${ }^{19}$.

4. Звукові образи (соносфера) - ті звукові образи, які автор відтворив в своєму творі. До них належать звуки природи, звуки, породжені людською життєдіяльністю, музичні звуки тощо. Звукові образи можуть відігравати різні функції (деталізацію подій; підсилення наданого опису/тексту; надання події експресивності; надання події символічності; надання комічного ефекту; експлікацію глибини підтексту): «Вечно глядел бы и не нагляделся на эту чудную картину слушал бы и не наслушался этих звуков без слов, но полных радостной жизни!»; «По звуку стаканов и бутылок можно было заключить, что они сопровождали свой спор обильными возлияниями» ${ }^{20}$.

5. Зорові образи - деталізація кольорів, контурів тощо. До функцій таких образів можна віднести деталізацію подій, надання експресивності, створення асоціативних полів, емотивність: «И так, понеже ноч весьма темная была, пришел я на весьма грязное место, в котором как начал погрузать» ${ }^{21}$; «Я ходил за грибами, собирал щавель, который составлял тогда мое единственное лакомство, и молоденькие еловые шишки, привлекавшие меня красноватым цветом и тонким смолистым запахом» ${ }^{22}$.

6. Смакові образи - до смакових образів відносимо образи їжі. Подібні образи відіграють функції деталізації, експресивності, експлікації прихованої інформації: «Я голодом был морим, требовал

18 Фальківський Іриней. ... С. 20-21.

${ }^{19}$ Мое время. Записки Г.С. Винского... С. 513.

${ }^{20}$ Никитенко А.В. Записки и дневник... С. 22, 124.

${ }^{21}$ Фальківський Іриней. ... С. 27.

${ }^{22}$ Никитенко А.В. Записки и дневник... С. 1. 
есть, и дали мне мясо холодное с капустою, которого я и половины не съел: ибо оно мне так противным показалось, что я все, что ел, тотчас выблевал» ${ }^{23}$; «Три или четыре турка принесли на больших жестяных досках (в роде подносов) обед, для солдат чорбу (похлебку из сарачинской крупы), а для нас, кроме чорбы, еще баранину, приготовленную какими-то двумя способами, и пилав, вместо масла, облитый бараньим жиром» ${ }^{24}$.

7. образи-заnахи - до цієї підгрупи можна віднести природні та штучні запахи. Подібні образи створюються з метою деталізації подій, експресивності: «В воздухе, пропитанном запахом молодой листвы, было что-то бодрящее и тело, и дух. При всем моем предубеждении против угрюмой северной природы, я весь отдался обаянию этого чудного дня - одного из редких, какие дарит петербургская весна»; «Чистый, благорастворенный воздух давно не освежал моей крови, и я с жадностью глотал его. Запах молодых березок не может сравниться ни с каким ароматом, веющим от наших модниц и модников» ${ }^{25}$.

8. Образи-подіï, образи-вчинки - ця підгрупа $є$ надзвичайно важливою для тексту мемуарів 3 огляду на те, що в мемуарах автори описують яскраві події з власного життя, життя оточуючих людей, опис вчинків персонажів, які мали певний вплив, наклали відбиток на їхнє життя: «Между тем приближался месяц Июнь, грозя нам, увы, великим нещастиям, Провидение Божие изволило малую нашу фамилию уменьшить смертию любезнейшего нашего брата Стефана. Ах! жестокая то язва была!»; «Здесь учил я своего ученика полтора месяца, а за плату не договорился, уповая на его учтивство. Но он в кратком времени небрежению себя предав, начал гнушатся науками: потом оставив школы содружился с некоторым развращенным студентом; который в Пресбурге мой сожитель был, и весьма много мне досаждал» ${ }^{26}$.

9. Образи-характери - підгрупа також $\epsilon$ вагомою для тексту мемуарів, як i попередньо розглянута підгрупа. Опис характерів персонажів є однією з фундаментальних груп у системі художніх образів мемуарів. Так, у творах мемуарів автори репрезентують власну оцінку персонажів та себе 3 огляду на риси характеру героїв (власні риси характеру) та характерні вчинки персонажів, використовуючи переважно такі стилістичні засоби, як епітети, метафори, іноді застосовуються порівняння: «Егор Федорович быль замечательнаго ума, отличался необыкновенной памятью, честностью и образцовою деликатностью и аккуратностью; в своей частной жизни он всего более любиль тишину и

${ }^{23}$ Фальківський Іриней... С. 1.

${ }^{24}$ Розальон-Сошальский А. Г. Записки русского офицера... С. 1.

${ }^{25}$ Никитенко А.В. Записки и дневник... С. 87, 104.

${ }^{26}$ Фальківський Іриней... С. 9, 19. 
спокойствіе» ${ }^{27}$; «Въ последней, где населеніе издавна отличалось темпераментом буйным и безпокойным, сотенный атаман отнял у войта ключи кружечнаго двора и велел козакам самим продават вино» ${ }^{28}$; «Вотчим мой, будучи от природы человек угрюмый и сердитый, к нам весьма был неласков; но сам, сколько помнится, меня никогда не бивал, а исправлял сие через нашу несчастную мать, которая, как теперь помню, при наказаниях иногда сама горько плакивала» ${ }^{29}$.

1.2. Група образів, яку сформовано за смисловою узагальненістю, поділяється на такі підгрупи, як: індивідуальноавторські образи, образи, характерні людям початку XIX століття, типові образи, образи-мотиви, образи-архетипи. Ця група образів використовує такі лексичні одиниці: ідіоматичні вирази; нові слова, утворені автором; використання біблеїзмів; використання жаргонізмів; використання епітетів; використання порівнянь.

1. Індивідуально-авторські образи - характерні для твору тільки окремого письменника, оскільки вони $\epsilon$ творінням його уяви та характеризують його індивідуальний стиль: так, для твору Сгора Федоровича Тимковського індивідуально-авторськими образами $\epsilon$ часте використання релігійних та містичних образів, застосованих як у прямому, так і в переносному сенсі: «Неужели, на заре моей жизни, непостижимое провиденіе так ясно произнесло два непреложных приговора в моей судьбе, кои сбылись на самом деле: большую часть государственной службы моей имел я честь проходить в дипломатическом корпусе и - что всего поразительнее - я был в сердце Поднебесной имперіи, и несколько времени провел в китайском столичном городе Пекине, иди Бейдзине» ${ }^{30}$. Або ось: «Так шандеизм может, при тщательном розыскании, развязывать запутаннейшие узлы, и по нему же «дети порочной любви редко бывают добрыми существами; сын же распутныя не может быть иное, как изверг» ${ }^{31}$.

2. 3 огляду на те, що в роботі аналізуються особливості поетики мемуарної прози українських авторів перших десятиріч XIX століття, то в подібних мемуарних творах присутні образи, які характерні виключно людям початку XIX столітmя: «Для козака воевода великая невзгода», заметил еще Лазарь Баранович» ${ }^{32}$; «Или сей младый сын истиннаго кормильца всех других существ не доказывает ли ярким румянцем своих щек, упругостию своих мышц, широкою грудью,

27 Воспоминания Егора Федоровича Тимковского (С предисловием Н. Шугурова). Киевская старина. 1894. Т. 44. № 1-3. С. 365.

${ }^{28}$ Горленки... С. 201.

${ }^{29}$ Мое время. Записки Г.С. Винского... С. 513-514.

${ }^{30}$ Воспоминания Егора Федоровича Тимковского... С. 366.

${ }^{31}$ Мое время. Записки Г.С. Винского... С. 509.

${ }^{32}$ Горленки... С. 200. 
звонким голосом, своею всегдашней веселостию, что он чадо советнаго союза, засеянное дюжим, трудолюбивым земледельцем в ложесна дородныя, здоровыя подруги, вынесшей в поле сытный обед, или после общих летних работ, в тени ли ветвистых рощ, или в холодке душистаго стога?» ${ }^{33}$.

3. Tuповi образи - образи, що демонструють найвищий ступінь характерності. Такими образами можуть стати прототипи відомих людей, які володіють певними характеристиками та $є$ уособленням загальнолюдських рис: «И так я вам позволяю духовную любовь, полагая же, что и плотская умеренная и осторожная, (понеже мы не ангелы), позволительна, вижу однако и чувствую, что нежная мне вовся неприятна; и я оной терпеть не могу» ${ }^{34}$; «Чрез несколько дней привыкши, как к карканью ворон, к ругательствам русскаго благородства, я приложил все мое старание открыть, на чем вообще основали свое мнимое преимущество господа москали над малороссами» ${ }^{35}$.

4. Образи-архетипи - загальнолюдські образи, які володіють властивістю повсюдності. Такі образи містять у собі стійкі концепції, вкорінені в свідомості та уяві людини. Вони включають у себе культурні, міфологічні, соціальні образи. Образи-архетипи збагачуються новим змістом у кожній епосі: «Проклятая тварь! (т.е. Сатана) сказал я ему, теперь ты меня несколько дудков лишил» ${ }^{36}$; «Меньшій брат отца моего Иван Назарьевич Тимковскій, служившій в Глухове, в Малороссійской Коллегіи, при первом известіи о смерти его, движимый высоким христіанским усердіем, оставил все преимущества службы и немедленно явился посреди нашего семейства, как ангель-хранитель» ${ }^{37}$.

1.3. Структурна класифікація образів залежно від співвідношення предметного та смислового аспектів містить у собі такі підгрупи, як автологічні, металогічні та алегоричні або символічні образи. Структурні образи формуються за допомогою таких лексичних засобів, як: епітети; метафори; порівняння; метонімії; алегорія.

1. Автологічні образи характеризуються співпадінням предметного та смислового образів. Це образи, передані за допомогою звичайних мовних засобів, без застосування художньо стилістичних тропів та фігур: «Траянов вал, о котором я пишу, идет от Черного моря, при крепости Кистенжи, к Дунаю, у урочища Черноводы. Карасу есть средина оного, простирающаяся на 47 верст. Вал теперь весьма

\footnotetext{
${ }^{33}$ Мое время. Записки Г.С. Винского... С. 509.

${ }^{34}$ Фальківський Іриней... С. 16.

${ }^{35}$ Мое время. Записки Г.С. Винского... С. 529.

${ }^{36}$ Фальківський Іриней... С. 16.

${ }^{37}$ Воспоминания Егора Федоровича Тимковского... С. 367.
} 
приметен, и кто из вас не знает, что вообще дела Римских рук и самое время не может истребить?» ${ }^{38}$; «Пестрая толпа чинно, почти угрюмо бродила по дорожкам; нигде веселья, а везде только одно любопытство. Гуляющие казались не живыми лицами, а тенями, мелькающими в волшебном фонаре. Несколько больше движения замечалось у палаток, над входами в кои виднелись надписи: «Лондон», «Париж», «Лиссабон» и проч.» 39 ; «Псовники, в назначенный день для выезда на охоту, с полуночи наполняют весь дом шумом: клики людей, ржание коней, лай и вой собак, заставляя деревенских ответствовать тем же, разбужают все живущее в селении и, вынуждая к тому же рыкание испуганных коров, блеяние овец, визг свиней, плач детей, вопли баб, составляют такой адский концерт, который всех воробьев полусонных выгоняет из гнезд» ${ }^{40}$.

2. Металогічні - образи, які було застосовано в переносному значенні: «Коляска будто бы вместо 6-ти лошадей, 6 крыльев имела, ужасно быстро бежала» ${ }^{41}$; «Кь 1-му января 1668 года Горленко был вызван из Прилук в гетманскую резиденцію, Гадячь, куда уже съехались, по приглашенію гетмана, шесть других полковников. Брюховецкій, надежды котораго рушились перед безсиліем московскаго правительства, чувствуя уже, что почва ускользала изъподь его ног, на секретной раде у себя в доме предложил старшинам отказаться от всякой солидарности с Москвой и, вместе с Дорошенком, самим отстаивать самобытность і независимость Украйны» 42 ; «Но фортуна не присутствовала при моем рожденіи» ${ }^{43}$.

3. Алегоричні або символічні образи характеризуються повною розбіжністю предметного та смислового планів. Їх зміст характеризується абстрактністю, багатозначністю та узагальненістю: «Гроза надвигалась и глухо рокотала, словно ожидая перваго удара, чтобы разразиться съ подвой силой» ${ }^{44}$; «Я отказался от предлагаемого мне в Ярославле места. Там ожидало меня спокойствие и обеспеченность, здесь бури, превратности, но более обширное поле деятельности. Я избираю последнее» ${ }^{45}$.

У ході проведеного аналізу всі образи творів української мемуарної прози початку XIX століття було класифіковано таким чином:

\footnotetext{
38 Записки инженерного офицера Мартоса... С. 314.

${ }^{39}$ Никитенко А.В. Записки и дневник... С. 148.

${ }^{40}$ Мое время. Записки Г.С. Винского... С. 613.

${ }^{41}$ Фальківський Іриней... С. 16.

${ }^{42}$ Горленки... С. 200.

${ }^{43}$ Воспоминания Егора Федоровича Тимковского... С. 366.

${ }^{44}$ Горленки... С. 200.

${ }^{45}$ Никитенко А.В. Записки и дневник... С. 142.
} 
1. Образи, які згруповано за предметом образності, які включають у себе: 1) деталізацію: опис інтер'єрів; подій, переміщень героїв; пейзажів, опис навколишнього світу; архітектурних пам'яток; деталізацію історичних подій; події у колі влади; події у колі суспільства; події в особистому житті; 2) предметні образи: образипредмети; 3) образи-думки та образи-переживання; 4) звукові образи (соносферу); 5) зорові образи; 6) смакові образи; 7) образи-запахи; образи-події, образи-вчинки; 8) образи-характери.

2. Образи, згруповані за смисловою узагальненістю, включають у себе: 1) індивідуально-авторські образи; 2) образи, характерні людям початку XIX століття; 3) типові образи; 4) образи-архетипи.

3. Образи, засновані за структурним принципом, включають у себе такі підгрупи: 1) автологічні образи; 2) металогічні образи; 3) алегоричні або символічні образи.

Таким чином, українська мемуарна проза початку XIX століття має вельми розгалужену систему образів, яка включає в себе велику кількість підгруп, що характеризує українську мемуарну прозу як глибоко поетичні художні творі, які володіють високим рівнем експресивності та образності у поєднанні з документальністю та реалістичністю жанру мемуарів.

\section{2. Образ автора в мемуарних творах перших десятиліть XIX ст.}

Автор - творець художнього твору, суб'єкт художньо-літературної діяльності, чиє уявлення про світ репрезентується у створеному ним творі. Автор, як творець, проявляється на всіх рівнях твору. У мемуарному творі образ автора має вивчатись 3 різних позицій: 1) як суб'єкт передачі інформації - реальна особа, яка розповідає про своє реальне минуле; 2) як суб'єкт мовлення - особа, яка продукує, розповідає та організовує розповідь; 3) як герой-персонаж розповіді.

У мемуаристиці автор відображає сюжетний центр спогадів: уся розповідь побудована крізь призму індивідуального сприйняття автора, пронизана його особистими судженнями, ідеями, вчинками. Всі події мемуаристичних творів автор репрезентує у відношенні до нього або демонструє його власне відношення до цих подій.

Важлива риса авторської позиції в мемуаристиці - це те, що автор завжди говорить від своєї особи. Таким чином, читач немов особисто бере участь у подіях, які описує автор у своєму творі. Автор мемуарів живий представник минулого, він не приховує правду, він подає іï як даність, очевидний факт. Особистість автора - структурний принцип, «стержень» мемуарного твору.

Автор мемуарів виступає і як носій достовірності, і як творець унікального художньо-образного світу. Так, автор не лише моделює 
себе і власну позицію - він формує дійсність, зображує події та характери.

Залежно від позиції автор мемуарного твору виступає як авторгерой (учасник подій минулого часу) та як автор-творець (творець часу написання твору).

Залежно від ступеня залученості автора в ході описаних подій можна виокремити такі форми авторського самовираження:

- Aвтор-творець: «Всегда чуждался я тщеславія. Повинуясь только убежденіям моих истинных друзей - оставить им письменное изложеніе разных случаев моей жизни, о коих разсказы в деревенском уединеніи слушали они с любопытетвом, я дал им слово как нибудь описать мою неизвестную жизнь. Долго, очень долго я колебался взяться за перо, уже изсохшее и притупленное разными переворотами в моей судьбе. Возобновились приглашенія, просьбы и - нечего делать! должно исполнить свое слово» ${ }^{46}$; «Все перечитавши, и несколько раз, что только нашлось своего или занятого, все передумавши и неоднократно, что только задержалось в моей старой голове, всем наскучивши, что только могла доставлять благодатная мечта, наконец с месяц нахожусь я в совершенном безделии, следовательно, в несносной скуке. Работать в огороде или бродить по окрестностям моего самопроизвольного заточения? Препятствует ежедневный жар. Выезжать на охоту? Стрелять в сие время нечего, к тому оводы одолевают коней. Чем же наполнять день, особенно чем сокращать недолгие предобеденные часы? Писать...» ${ }^{47}$ «Мысль сия явилась у меня от желания когда-нибудь передать сии Записки моим друзьям, которых я приобрел служа и которых выбором могу гордиться. Они мне простят за то, что некоторые материалы будут слишком растянуты, некоторые описаны кратко, ибо прощали мне и прежде в моей с ними переписке сии погрешности, которые строго не требуются от человека взрощенного в кругу военном и следовательно не имеющего ни случая, ни удобности и самой возможности соделаться красноречивым и приятным писателем» ${ }^{48}$.

- Aвтор-герой: «Между тем я в Токайском Римско-Католическом училище, состоящих из двух учебных горниц, разделенных на четыре класса, называемым: Glassis Principistarum; но для изучения венгерской грамматики, обучаемой вместе с Латинскою, учился я около половины года и в первом классе, подразделенном на 6 отделений, из коих 1-е было Minimistarum, то есть, обучающихся обоих языков чтению и

\footnotetext{
${ }^{46}$ Воспоминания Егора Федоровича Тимковского... С. 364-365.

${ }^{47}$ Мое время. Записки Г.С. Винского... С. 505.

48 Записки инженерного офицера Мартоса... С. 305.
} 
писанию» ${ }^{49}$; «3десь, в течении трех с половиною лет, упражнялся Антоновский в науках с такою ревностию, что первый год в философском факультете кончил словесныя науки, все части философии, чистую мафематику и опытную физику, а в последующие годы сверх сих наук и с отменным прилежанием обучался всем частям законоискусства теоретическаго и практическаго, судоведения и политики, и притом языкам Английскому, Французскому и Италиянскому, как гимнастическим упражнениям, фехтованию, танцованию, рисованию и другим» ${ }^{50}$ «В другой раз, ускользнув из дому, я побежал к реке. Там у причала стояла отвязанная лодка. Я мигом в ней очутился. Лодка отделилась от берега и потянулась вдоль по течению. К счастью, моя мать была недалеко, в огороде. Она перепугалась, увидев меня среди узкой, но глубокой реки, радостно махающего ручонками» ${ }^{51}$.

- Автор-суб'єкт мовлення: «Разсматривая безпристрастно время моей юности, открывается, что оно протекло для меня весьма невыгодно. От всего моего многолетняго учения приобрел я знание латинскаго языка и небольшое умение писать; существенныя же и необходимейшия для моего благоденствия знания, как святая нравственность и состав людских обществ, или яснее: «чем каждый человек обязан обществу, и наоборот, общество человеку», - до того мне были неизвестны, что я их и в числе наук, до сорока лет моей жизни, не считал» ${ }^{52}$; «Получив от генерала Гартинга повеление, я отправился обратно к Маратину, где был наведен понтонный мост... Мне досталось строить большую батарею для комплектного батальона с артиллериею на левой стороне Дуная, в 7-ми верстах от Журжи, близ урочища, называемого Чадырджи-оглу; работа была кончена поспешно» ${ }^{53}$; «Боясь, чтобы такое мнение при подозрительности турок не послужило поводом к каким-нибудь особенным ограничениям той свободы, которой пользуются военнопленные, я старался его уверить, что я был «атлы юз-баши» (офицер конного полка), однако напрасно, он оставался при своей мысли. Но я увидел впоследствии, что мои опасения были напрасны» ${ }^{54}$.

- Aвmop-cnocmepizaч: «Один из старших братьев моих, Романъ $\Phi .$, облеченный уже в Московском университет саном магистра филологіи, глубокій знаток греческой и латинской словесности и древней исторіи, пріехал летом того года к нам в деревню, повидаться с

49 Фальківський Іриней... С. 8.

50 Записки Михаила Ивановича Антоновскаго... С. 148.

${ }^{51}$ Никитенко А.В. Записки и дневник... С. 14.

52 Мое время. Записки Г.С. Винского... С. 518.

53 Записки инженерного офицера Мартоса... С. 323.

${ }^{54}$ Розальон-Сошальский А.Г. Записки русского офицера... С. 33. 
родными, отдохнуть после ученья и трудов...» ${ }^{55}$ « «енерал-майор Хитров, с отрядом левее нас, занял горы над городом, в виноградных садах; генерал-майор князь Вяземский и полковник граф Орурк приняли левее его, и таким образом, левым флангом осаждающий корпус примкнул к реке Лому, предоставив гарнизону большую Систовскую дорогу» ${ }^{56}$; «Нельзя оставить здесь без замечания, с какою осторожностью г. Кушелев ответствовал г. Голенищеву-Кутузову, когда сей 1797 года Марта 17 дня просил его исходатайствовать у Его Императорскаго Высочества отмену своего высочайшаго повеления в разсуждении определения Антоновскаго главным инспектором в Морской Кадетский Корпус» ${ }^{57}$.

- Автор-активний учасник подій: «По прожитии в Киеве однаго года, и около 4 месяцев, отец мой со мною, с меньшим моим братом, Стефаном, и с служителем Павлом Дорошенковым, решился ехать в Венгрию в город Токай, по определению бывшаго тогда Преосвященнаго Митрополита Киевского, Гавриила (Кременецкаго) по которому надлежало ему быть при церкви Российской Токайской Коммисии Капеляном. Все сие обстоятельно можно усмотреть из данных ему тогда в месяце Генваре, указа, Инструкции и Пашпорта, с коих верная копия» ${ }^{58}$; «Дни моего детства протекли во всей простоте сельской жизни. Я рос вместе с двумя моими сестрами, несколько старшими от меня, следовательно без товарищей. Как самое меньшее дитя, я быль предметом особенной нежности матери, которая впрочем, по своей разсудительности, не позволяла мне лишняго баловства» ${ }^{59}$; «Затем я вижу всех нас в просторных крытых санях. Дело было зимой. Возле меня, по одну сторону, угрюмый и мрачный отец, по другую мать с закутанным в тулупчик годовалым ребенком на коленях: это ее второй сын, Григорий. Нас сопровождали два сторожа» ${ }^{60}$.

- Автор-активний коментатор подій: «Таким образом Горленко, в противоположность другим своим товарищам по несчастью, не только наружно примирился с Самойловичем, но и на деле до самой своей смерти оставался верным его сторонником, а женитьба сына его, Димитрія, на родной племяннице гетманши еще более сблизила недавних врагов» ${ }^{61}$; «В ясный осенний день, после обеда, на тройке удалых, с тремя залетными молодцами, отправился я провожать гостя. За обедом и при выезде выпито было, видно, порядочно; поелику я, прибывши в обитель, едва мог

\footnotetext{
${ }_{55}^{55}$ Воспоминания Егора Федоровича Тимковского... С. 381.

56 Записки инженерного офицера Мартоса... С. 318.

57 Записки Михаила Ивановича Антоновскаго... С. 156.

${ }^{58}$ Фальківський Іриней... С. 5.

${ }^{59}$ Воспоминания Егора Федоровича Тимковского... С. 368.

${ }^{60}$ Никитенко А.В. Записки и дневник... С. 15.

${ }^{61}$ Горленки... С. 219.
} 
различать предметы. На беду, товарищ мой во хмелю был один из задорнейших; а тут случился в гостях какой-то панок, с которым у Острожскаго моего скоро начался диспут, а там и сражение» ${ }^{62}$; «Мустафа был готов лететь к нам на помощь, но осыпанный упреками начальника, товарищей и других турок за такую снисходительность к неверным, он остался, грозя только, если нам не дадут удовлетворения, донести паше о том, что не поступали по его повелению. Пришел другой кавас и с недовольным видом исполнил наше требование. Караульные, разложив огонь у избы, вымещали бранью сквозь зубы за потерю для них ночи» ${ }^{63}$.

- Aвтор-фiксатор: «2-го марта 1770 года повезли меня из Глухова в С.-Петербург. Утопая в слезах, простился я с любезною Малороссиею, как бы предчувствуя вечное мое из оной удаление. До Орла я ничего не видал, не чувствовал» ${ }^{64}$; «Но когда все кончилось, и почтовая тележка была готова, я истинно раскаивался своему намерению, - бросил из головы бить Турок, плакал, как ребенок, сам не зная от чего, и 4-го Марта по утру в 10 часов велел ударить по лошадям» ${ }^{65}$; «Повелено было, по закупке книг Российских и Славянских с самаго начала печатания оных как в чужих краях, так и в России, как и иностранных с 1770 г. (ибо по тот год почти все существовали уже в сказанных библиотеках) по 1796 г. всех книг, какия токмо ни отыщутся уже в оных библиотеках, отобрав особо находящияся в оных в двойне, тройне, четверне, для разослания оных во все ${ }^{66}$.

- Aвтор-філософ: «Возьмите вы, на пример: очень малое детя в руки хотя и пред великим собранием народа, и обнимая оное, или и целуя, говорите умелительныя оныя нежныя слова: то никто вам, думаю в порок не причтет. Смеетесь вы и с большаго возраста лицем пред тем же собранием народа сие самое делать? И так я вам позволяю духовную любовь, полагая же, что и плотская умеренная и осторожная, (понеже мы не ангелы), позволительна, вижу однако и чувствую, что нежная мне вовся неприятна; и я оной терпеть не могу. <...>. Но я еще к сему замечаю, что от слепой влюбчивости происходящее как господство хуже разумнаго рабства, так и рабство хуже безумнаго самоволия» ${ }^{67}$; «Думалось-ли старому козацкому вождю, когда онъ в последній раз оглянулся на скрывшіеся за поворотом гадяцкаго шляха свои подгородные прилуцкіе хутора, что он прощается с ними на

\footnotetext{
${ }^{62}$ Мое время. Записки Г.С. Винского... С. 552.

${ }^{63}$ Розальон-Сошальский А Г. Записки русского офицера... С. 28.

${ }^{64}$ Мое время. Записки Г.С. Винского... С. 557.

65 Записки инженерного офицера Мартоса... С. 309.

66 Записки Михаила Ивановича Антоновскаго... С. 160.

${ }^{67}$ Фальківський Іриней... С. 21.
} 
всегда? ${ }^{68}$; «Казалось, мы глядели на своих родных, и сердце билось какою-то ребяческою радостью при виде щеголеватых европейских костюмов, после того, как мы так долго видели одни чалмы, шубы и шальвары, из-под которых выходили грязные ноги, обутые в неуклюжий башмак. «Может быть, думал я, эти люди, близкие ко мне по столь многим отношениям, спешат теперь к своим знакомым, друзьям или семействам, $-\mathrm{a}$, я?»...» ${ }^{69}$.

- Автор-творець художнього твору: «Плаваніе по Днепру в дубе, большой шлюпке, на отдаленный острова, в обществе взрослых уже студентов, занимало меня самым пріятным образом. Подробности такого катанья, сборы, личное приготовленіе пищи и маленькія на воде опасности воспламеняли мое воображеніе, и я мысленно представляль себя, ежели не Колумбом, то никак не меньше Кука, коего путешествіе вокруг света было первою книгою, какую прочитал я, научившись хорошо читать и разуметь» ${ }^{70}$; «Мелодрама открылась наряднейшим Императрицы въездом в Москву, предшествуемой и сопутствуемой блистательным двором, видными полками телохранителей и безчисленным народом. Торжественные врата, взгроможденные на скорую руку хотя из лубков и рогож, но раскрашенные, раззолоченные и в приличных местах убранные соответственными предмету картинами, восхищали всех до безумия; к чему присоединяя военную музыку, колокольный звон и пушечную пальбу, каждый может себе вообразить, что сие очаровательное явление, невзирая на лютую зиму, было безподобно» ${ }^{71}$; «Боже, какая трогательная картина видеть сих бледных страшилищ! Как горестно было слышать их всхлипывания, их прощания с друзьями, родными своими, их наказы, повторения, что сказать у себя дома. Я скоро далеко отъехал от сих мрачных сцен, но они глубоко; вкоренились в моем сердце» ${ }^{72}$; «Ночлеги эти оставили во мне неизгладимое впечатление. Никакое перо не в силах передать очарования мирных степных сцен, зрителем которых я тогда был. Все вокруг дышало изящной простотой и было полно неуловимой прелести, которую я ощущал всем существом. Стрекотание кузнечика в душистой траве, шелест крыльев пролетавшей в вечернем сумраке птицы... Как сладко засыпал я при тихом сиянии звезд! Каким свежим, бодрым просыпался с первыми лучами солнца, не скрытого ни стенами, ни занавесками, но бившего прямо в лицо!» ${ }^{73}$.

${ }^{68}$ Горленки... С. 226.

${ }^{69}$ Розальон-Сошальский А.Г. Записки русского офицера... С. 43.

${ }^{70}$ Воспоминания Егора Федоровича Тимковского... С. 375.

${ }^{71}$ Мое время. Записки Г.С. Винского... С. 540.

72 Записки инженерного офицера Мартоса... С. 347.

${ }^{73}$ Никитенко А.В. Записки и дневник... С. 21. 
Отже, у підсумку зазначимо, що образ автора представлено комплексною структурою, яка включає в себе такі компоненти, як: автор-творець; автор-герой; автор-суб'єкт мовлення; автор-спостерігач; автор-активний учасник подій; автор-активний коментатор подій; автор-фіксатор; автор-філософ; автор-творець художнього твору.

\section{ВИСНОВКИ}

Мемуарна проза, як феномен культури, характеризується певними художньо-стильовими особливостями. Тому було проведено грунтовне комплексне дослідження специфіки художньо-стильової організації мемуарних творів відомих на той час, сьогодні майже забутих, українців перших десятиріч XIX століття.

Аналіз спогадових творів українських мемуаристів перших десятиріч XIX століття показав, що систему образів можна поділити на три стрижневі групи:

1) Образи, які згруповано за предметом образності. Сюди ми відносимо комплекс таких образів, як: деталізація (опис інтер'єрів; подій, переміщень героїв; пейзажів, опис навколишнього світу; архітектурних пам'яток; деталізація історичних подій; події у колі влади; події у колі суспільства; події в особистому житті); предметні образи (образи-предмети; образи-думки та образи-переживання; звукові образи (соносфера); зорові образи; смакові образи; образизапахи; образи-події, образи-вчинки; образи-характери).

2) Образи, що згруповані за смисловою узагальненістю, сюди належать такі образи, як: індивідуально-авторські образи; образи, характерні людям початку XIX століття; типові образи; образиархетипи.

3) Остання, третя група - образи, засновані за структурним принципом, - включає в себе такі образи, як: автологічні образи; металогічні образи; алегоричні або символічні образи.

Проаналізувавши способи творення образів мемуарного тексту, було 3'ясовано, що для першої групи характерними засобами творення $€$ такі лексичні засоби, як епітети, порівняння, статистична інформація; застосування правдивих дат, кількісних показників; застосування одиниць мір, грошових одиниць; застосування реалій, характерних для першої частини XIX ст.

Для творення образів другої групи використовуються такі лексичні одиниці, як ідіоматичні вирази; нові слова, утворені автором; використання біблеїзмів; використання жаргонізмів; використання епітетів; використання порівнянь. Остання група образів утворюються за допомогою таких лексичних засобів, як: епітети; метафори; порівняння; метонімії; алегорія. 
Система образів української мемуаристики початку XIX являє собою складну та розгалужену структуру, тому такі твори мають повне право називатись художніми поряд 3 їх документальністю та реалістичністю.

Автор відіграє в мемуарному творі важливу роль. Так, він постає в таких образах, як: автор-творець; автор-герой; автор-суб'єкт мовлення; автор-спостерігач; автор-активний учасник подій; автор-активний коментатор подій; автор-фіксатор; автор-філософ; автор-творець художнього твору.

Українська мемуаристика початку XIX ст. розширює наші знання про суспільно-політичне і культурне життя того періоду, збагачує нас маловідомими деталями і фактами життя і творчості українських письменників, допомагає глибше осягнути драматизм епохи, коли закладалися основи наших політичних, національних і культурних традицій. Умови сьогодення відкривають нам перспективи для неупередженого вивчення українських спогадів. Епоха розбудови української державності, потреба виховання національної свідомості, плекання паростків керівників-державників викликають необхідність у розкритті творчих набутків минулого, які через ідеологічне табу довгий час залишалися поза увагою нації.

\section{АНОТАЦІЯ}

На основі аналізу творів мемуарного пласту української літератури початку XIX ст. досліджено їх жанрово-стильові особливості; простежено, як у мемуарах проявляються особистісні риси їх авторів; зроблено спробу розрізнення використання у метажанровій системі мемуаристики таких понять, як «образ автора», «оповідач і герой», «авторське начало».

Доведено, що українська мемуарна проза початку XIX століття має вельми розгалужену систему образів, яка включає в себе велику кількість підгруп, що характеризує ії як художні творі, які володіють високим рівнем експресивності та образності у поєднанні 3 документальністю та реалістичністю жанру мемуарів. Проаналізовано образ автора, що представлений комплексною структурою, яка включає в себе такі компоненти, як: автор-творець; автор-герой; автор-суб'єкт мовлення; автор-спостерігач; автор-активний учасник подій; авторактивний коментатор подій; автор-фіксатор; автор-філософ; автортворець художнього твору. В образі автора органічно поєдналися як ліричне, так і епічне начала. Світогляд автора простежується не лише позасуб'єктно (характер, сюжет, психологічна основа образності), а й у самій внутрішній композиції творів як вияві глибинних суб'єктнооб'єктних структурних зв'язків його художнього світу. 
Використання результатів допоможе розв'язати проблему дослідження української мемуарної літератури, сприятиме кращому розумінню особливостей розвитку історії українського письменства в період колоніальної залежності нашої держави. Матеріали дослідження можуть стати підгрунтям для цілісного вивчення явища української мемуарної літератури в майбутньому.

\section{ЛIТЕРАТУРА}

1. Воспоминания Егора Федоровича Тимковского (C предисловием Н. Шугурова). Киевская старина. 1894. Т. 44. № 1-3. С. 359-381; Т. 45. № 4-6. C. 1-25.

2. Горленки (Очерки прилуцкой старины). Киевская старина. 1887. № 2. С. 237-268; № 10. С. 199-232.

3. Записки инженерного офицера Мартоса. 1806-1812. Русский архив. 1893. Кн. 2. С. 305-368, 449-542.

4. Записки Михаила Ивановича Антоновскаго (Начаты въ 1806 году). Руский архив. Киев, 1885. Кн. 1. С. 145-178.

5. Мое время. Записки Г.С. Винского; предисловие А.И. Тергенева. Русские люди XVIII века / отв. ред. О.А. Платонов. Москва : Институт русской цивилизации, 2015. С. 503-630.

6. Никитенко А.В. Записки и дневник: в 3 т. Москва : Захаров, 2005. T. $1.640 \mathrm{c}$.

7. Розальон-Сошальский А.Г. Записки русского офицера, бывшего в плену у турок в 1828 и 1829 годах. Харьков; Київ : Харьковский частный музей городской усадьбы; ИД «Стилос», 2006. 128 с.

8. Фальківський Іриней. Біографические известия. IP НБУ ім. Вернадського. Ф. 175. № 2214. 100 с.

9. Эпштейн М. Проективный словарь философии. Новые понятия и термины. URL: http://topos.ru/article/1676.

\section{Information about the author: Kandiuk-Lebid S. V., Director of Mykolaiv College} Higher Education Institution "Open International University of Human Development "Ukraine" 22, 2-a Viiskova str., Mykolaiv, 54003, Ukraine 